\title{
Incidence of preleukemic fusion genes in healthy subjects
}

\author{
Minireview
}

P. KOSIK, M. SKORVAGA, I. BELYAEV*

Department of Oncology, Cancer Research Institute, Biomedical Research Center, Slovak Academy of Sciences, Bratislava, Slovak Republic

${ }^{*}$ Correspondence: Igor.Beliaev@savba.sk

Received April 26, 2016 / Accepted May 18, 2016

\begin{abstract}
The diagnostics of leukemia relies upon multi-parametric approach involving a number of different pathology disciplines such as flow cytometry, histopathology, cytogenetics and molecular genetics [fluorescent in situ hybridization (FISH) and polymerase chain reaction (PCR)]. Childhood leukemia is often determined by the presence of specific chromosomal translocation that entails the generation of preleukemic fusion genes (PFG). In the last two decades, several studies have reported observations that PFG are present in healthy population and not necessarily result in leukemia. The first such study by Limpens and colleagues on $\mathrm{t}(14 / 18) / B C L 2-J H[1]$ and next in line [2,3] led to many questions regarding the significance of these chromosomal translocations in leukemogenesis. However, the data on the incidence of PFG are contradictive. This review aims to highlight the molecular genetic approaches used by various studies with regard to differences in diagnostics and incidence of PFG in healthy subjects. The focus is on the incidence and prevalence of the most common PFG such as TEL-AML1, MLL-AF4, BCR-ABL (p190), AML1-ETO, PML-RARA, and CBFB-MYH11 detected in umbilical cord blood, in neonatal blood spots (Guthrie cards (GC)), bone marrow, peripheral blood and tissues of amortized fetuses. We conclude that the incidence of PFG is significantly higher than incidence of leukemia and more sophisticated analysis of PFG in leukemogenic cell populations is warranted to relate the occurrence of PFG with leukemia. The emerging notion is that only those PFG may contribute to development of leukemia which arise in stem cells at specific time windows during development. Thus, screening of PFG in subpopulations of stem cells may be a challenge for assessment of predisposition to leukemia and for validation of cell transplant to minimize donor cell-derived leukemia.
\end{abstract}

Key words: preleukemic fusion genes, childhood leukemia, stem cells

Leukemia is a cancer characterized by abnormal proliferation of hematopoietic cells. It is the most common cancer in children representing about $30 \%$ of all childhood cancers, where acute lymphoid leukemia (ALL) at $81 \%$ is the most fre-

\footnotetext{
Abbreviations: ALL - acute lymphoblastic leukemia; AML - acute myeloid leukemia; BM - bone marrow; CML - chronic myeloid leukemia; DCL - donor cell-derived leukemia; FISH - fluorescent in situ hybridization; GC - Guthrie cards; HSC - hematopoietic stem cells; HSC/PC -hematopoietic stem /progenitor cells; LIC - leukemia-initiating cells; LSC - leukemia stem cells; MNC -mononuclear cells; PB -peripheral blood; PCR -polymerase chain reaction; PFG - preleukemic fusion genes; RT qPCR - real-time quantitative PCR; RT PCR - reverse transcription PCR; UCB - umbilical cord blood; WBC - white blood cells
}

quent leukemia in Europe, followed by acute myeloid leukemia (AML) with 15\%, and other three, markedly rare subgroups of chronic myeloid leukemia (CML) at $1.5 \%$, unspecified $(1.3 \%)$ and other specified leukemia $(<0.5 \%)$ [4]. In childhood leukemias, there is a clear evidence that largely non-overlapping subtypes of disease may be identified based on the genetic abnormalities which they acquire. Chromosomal translocations as a consequence of double-strand breaks (DSB) are the most common genetic aberrations in leukemias and one of the tumor hallmarks $[5,6]$. Depending on the chromosome breakpoints, a translocation can result in formation of so-called preleukemic fusion gene (PFG) followed by a disruption or mis-regulation of the normal gene function $[7,8]$. 
Common chromosomal translocations in pediatric leukemia include $\mathrm{t}(12 ; 21) / T E L-A M L 1(\sim 25 \%), \mathrm{t}(11 ; 4) / M L L-A F 4$ ( 5\%), $\mathrm{t}(9 ; 21) / B C R-A B L(\sim 5-10 \%), \mathrm{t}(1 ; 19) / E 2 A-P B X 1(\sim 5 \%)$ for B-lineage ALL, and $\mathrm{t}(15 ; 17) / P M L-R A R A(15 \%), \mathrm{t}(8 ; 21) /$ AML1-ETO (4-11\%), and inv(16)/CBFB-MYH11 (8-12\%) for AML. Many of them are present also in other types of leukemia and adults, e.g. $87 \%$ of patients with CML harbor $B C R-A B L$ [9]. Other very frequent chromosomal aberrations include high hyperdiploidy with 51-60 chromosomes, hypodiploidy (<44 chromosomes) and rearrangements of $\mathrm{IgH}$ and TCR genes [10], however, these lesions will not be discussed in this review.

Cytogenetically different ALL subtypes create clinically and biologically distinct entities of disease. Distribution of ALL subtypes is uniquely divided based on age. The TEL-AML1 ALL occurs at very high frequency between 2 and 5 years of life and almost completely absents in adults. In contrast, $M L L$ AF4 ALL often appears early after the birth and the incidence of $B C R-A B L$ increases with age. Importantly, specific genetic subtypes are often associated with initial treatment response, a therapy-depending risk of relapse and the overall survival rate $[11,12]$. Poor prognosis is preferentially associated with chromosomal breakpoints within the MLL intron (e. g. $M L L$ AF4) with $<50 \%$ of 5 -year overall survival, despite the fact that patients receive a very intensive chemotherapy $[13,14]$. TEL-AML1 showed excellent prognosis (>90\% survival) with intensive doses of L-ascorbic acid 2-phosphate magnesium [15]. The therapeutic outcome for ALL associated with $B C R-$ $A B L$ has been improved after using tyrosine kinase inhibitors, however, it is still poor, with event free survival $~ 70 \%$ and a high resistance to therapy $[16,17,18]$.

Epidemiological evidence has suggested that some pediatric leukemia may be initiated by the formation of PFG prenatally after exposure to external factors. Ionizing radiation, chemotherapy or genetic disorders are known risk factors for leukemia, but explain only a small fraction of cases $[19,20]$. There are few lines of evidence suggesting prenatal origin of pediatric leukemia: (i) a common clonal origin of concordant leukemia in monozygotic twins via monochromic placental vasculature $[21,22,23]$; (ii) the presence of PFG in archived neonatal blood spots [24]; (iii) findings obtained by molecular screening of umbilical cord blood (UCB) for PFG [2]. Several scientific groups have later described the incidence of PFG in UCB of the healthy population $[2,3,25,26,27]$. While the data were not always consistent, most of the groups reported that the incidence of PFG-positive UCB exceeded about 100-fold the incidence of leukemia. Obviously, reliable estimation of PFG in UCB hematopoietic stem/progenitor cells (HSC/PC) with leukemogenic potential may be diagnostically important [28].

In addition to UCB samples, different sources of hematopoietic cells, such as peripheral blood (PB) from children or adults, infant bone marrow (BM), fetal BM or liver from amortized fetuses were screened. Most of the studies investigated TEL-AML1 and BCR-ABL fusion genes. Other PFG were described only sporadically. In all cases, nested PCR (RT PCR) or real-time quantitative PCR (RT qPCR) was performed as a primary screening method. For the verification of positive samples, different methods on RNA or DNA levels were used, such as re-screening by RT qPCR, nested RT PCR, Southern blot, dot blot, FISH and sequencing the PCR product. Brassesco reviewed the incidence of PFG in healthy individuals in 2008 [29]. BCR-ABL was then partially summarized by Ismail and colleagues [30].

The observations that some of PFG are present in healthy individuals have triggered more attention due to their significance in etiology of leukemia and possible significance for the donor cell-derived leukemia (DCL) [31]. Currently, more than 50,000 patients per year receive hematopoietic stem cell transplantation, typically to treat malignant diseases [32]. In some rarely cases, the treatment following BM or UCB allogeneic transplantation resulted in a 'relapse' associated with DCL [31]. During forty years, 76 reports of DCL following $24 \mathrm{UCB}$ and 52 BM transplantations were published in the National Library of Medicine's PubMed database [33]. In general, DCL have a poor prognosis, lower than $30 \%$, with a median duration of survival approximately 5 months. While mechanism of DCL remains speculative, the possibility that DCL may be triggered by preleukemic clone with PFG preexisting in transplant cannot be ruled out [34].

It is obvious that molecular and genetic methods are crucially important as they help to determine and refine diagnosis, estimate prognosis, and suggest the most appropriate treatment. Determination of the incidence of PFG highly depends on the sensitivity and specificity of the screening methods, which partially differ between laboratories and between treatment protocols.

The purpose of this paper was to give an update and overview of all available data on most frequent leukemia-associated PFG (BCR-ABL, MLL-AF4, TEL-AML1, AML1-ETO, PML-RARA and $C B F B-M Y H 11)$ in healthy subjects. Our review summarizes and compares all available data on the incidences of PFG in healthy individuals, and the methods. We focused on sensitivity and specificity of applied screening methods used, and sources of tested samples. For this aim, the main scientific databases including Web of Science and Scopus were searched through with relevant key words and all retrieved publications were considered.

In order to assure confidence in the results and conclusions of these studies, we have to take into consideration several important criteria, including (i) statistical power, ensuring sufficient number of subjects enrolled/screened in the study. For example, if the expected incidence of TEL-AML1 in cord blood is about $1 \%$, i.e. one positive case per 100 probands, the size of the sample should be at least 100, but preferably higher multiples of this number which can increase the chance of finding at statistically significant value, (ii) choice of a correct screening method, in terms of sensitivity, specificity and reliability. Sensitivity of the method quantifies its threshold for PFG detection. If the sensitivity of the screening assay is too low, we can expect to miss the real PFG values. In case when the positivity incidence is very close to the threshold of the method sensitivity, the final numbers may be 
rather semi-quantitative, representing an estimate of the actual PFG incidence. Specificity of the screening is aimed to minimize the amount of false positives in the sample set. Reliability of the screening is meant in terms of the risk of false positivity due to cross-contamination, therefore, inclusion of negative controls must be an essential part of the methodology. However, some methods are inherently susceptible to cross-contamination, especially nested PCR is notoriously known for contamination problems: opening the micro-tube after $1^{\text {st }}$ PCR could lead to false positive results through cross-contamination. From this point of view, the PFG incidences achieved by using two-tube nested PCR, especially when the numbers markedly stand out from the trend and could not be confirmed by other groups, cannot be considered as reliable, but they rather invoke doubts and should be excluded. In contrast, the RT qPCR with intro- duction of non-template controls (NTC) has an extremely low risk of cross-contamination and therefore, should be regarded as a reliable method.

\section{PFG molecular screening}

BCR-ABL fusion gene. BCR-ABL is one of the most investigated PFG in healthy people. According to the breakpoint location within the BCR gene, the resulting BCR-ABL fusion protein has two variants: shorter $190-\mathrm{kDa}$ protein (p190), which is more common in ALL, and longer $210-\mathrm{kDa}$ (p210), which is usually presented in CML. In three studies where $\mathrm{PB}$ has been tested, the correlation of both variants with age has been analyzed (Table 1). As a result, BCR-ABL p210 fusion transcript has shown significant upward trend with

Table 1. Incidence of $B C R-A B L$ in healthy subjects

\begin{tabular}{|c|c|c|c|c|c|c|}
\hline Studies & Source & Methods & Sensitivity & $\begin{array}{l}B C R-A B L \text { variant, posi- } \\
\text { tive/examined subjects } \\
\text { (incidence, } \% \text { ) }\end{array}$ & Subjects, age & Analyzed sample \\
\hline \multirow[t]{4}{*}{ Biernaux (1995) } & UCB & Nested PCR & Up to $10^{-8}$ & p210 0/22(0\%) & & $10^{8} \mathrm{WBC}$ \\
\hline & $\mathrm{PB}$ & Nested PCR & & p210 1/22 (4.5\%) & Children PB: $<13$ years & $4-10 \mu \mathrm{g}$ of total RNA for RT \\
\hline & & & & p210 22/73 (30\%) & Adult PB: $20-80$ years & \\
\hline & & Sequencing & & p210 23/23 (100\%) & & \\
\hline \multirow[t]{3}{*}{ Bose (1998) } & PB & Nested PCR & $10^{-5}-10^{-6}$ & p190 11/16 (68\%) & Adult: $23-46$ years & $10^{7} \mathrm{WBC}$ \\
\hline & & & & p210 4/15 (27\%) & Adult: $23-46$ years & total RNA \\
\hline & & & & & & 40 replicates \\
\hline \multirow[t]{4}{*}{ Uckun (1998) } & Fetal liver & Nested PCR & $10^{-4}$ & $0 / 13(0 \%)$ & Gestational age: & Total RNA \\
\hline & Fetal BM & Nested PCR & $10^{-4}$ & $0 / 16(0 \%)$ & $15-22$ weeks & \\
\hline & Neonatal BM & Nested PCR & $10^{-4}$ & $0 / 6(0 \%)$ & & \\
\hline & & Standard PCR & $10^{-2}$ & $0 / 35(0 \%)$ & & \\
\hline \multirow[t]{10}{*}{ Song (2011) } & UCB & Nested PCR & $10^{-4}$ & p190 21/50 (42\%) & & $8-16 \times 10^{6} \mathrm{MNC}$ \\
\hline & & & & p210 8/50 (16\%) & & $0.5 \mathrm{~g}$ total RNA for RT \\
\hline & $\mathrm{PB}$ & Nested PCR & $10^{-4}$ & p190 4/10 (40\%) & Newborns & $3 \mu \mathrm{l} \mathrm{cDNA} / 1$ round, $1 \mu \mathrm{l}$ \\
\hline & & & & p210 2/10 (20\%) & Newborns & $\mathrm{cDNA} / 2$ round $\mathrm{RT}$ PCR \\
\hline & & & & p190 22/29 (75\%) & Children $<25$ years & \\
\hline & & & & p210 11/30 (36\%) & Children $<25$ years & \\
\hline & & RT qPCR & $10^{-4}$ & p190 33/41 (80\%) & Adults $>25$ years & \\
\hline & & & & p210 21/34 (61\%) & Adults $>25$ years & \\
\hline & & & & p190 26/39 (67\%) & Children + Newborns & \\
\hline & & & & p210 13/40 (32\%) & Children +Newborns & \\
\hline Boquett (2013) & $\mathrm{PB}$ & Nested PCR & NA & P210 2/30 (6.67\%) & Adults $>$ 40years & $6 \mu \mathrm{l}$ total RNA for RT \\
\hline \multirow[t]{4}{*}{ Ismail (2014) } & $\mathrm{PB}$ & Nested PCR & $10^{-6}$ & p190 0/44 (0\%) & Children: $2-16$ years & $1 \mu \mathrm{g}$ RNA to RT \\
\hline & & & & p210 4/44 (9.1\%) & Children: $2-16$ years & \\
\hline & & & & p190 0/145 (0\%) & Adults: $20-86$ years & \\
\hline & & & & p210 15/145 & Adults: 20-86years & \\
\hline \multirow[t]{6}{*}{ Skorvaga (2014) } & UCB & RT qPCR 1 & $1-3 \times 10^{-5}$ & p190 50/200 (25\%) & & $10^{7} \mathrm{MNC}$ \\
\hline & & RT qPCR 2 & $1-3 \times 10^{-5}$ & p190 4/15 (26.6\%) & & $1 \mu \mathrm{g}$ total RNA to RT \\
\hline & & & & in total $6.25 \%$ & & $2 \mu \mathrm{l}$ cDNA per \\
\hline & & Nested PCR & $1-3 \times 10^{-5}$ & & & reaction \\
\hline & & Multiplex & $0.2-1 \times 10^{-3}$ & p190 0/135 (0\%) & & \\
\hline & & PCR & & & & \\
\hline \multirow[t]{4}{*}{ Kosik (2015) } & $\mathrm{UCB}$ & RT qPCR 1 & $1-3 \times 10^{-5}$ & p190 92/500 (18.4\%) & & $10^{7} \mathrm{MNC}$ \\
\hline & & RT qPCR 2 & $1-3 \times 10^{-5}$ & p190 27/90 (30\%) & & $1 \mu \mathrm{g}$ total RNA to RT \\
\hline & & Sequencing & & p190 20/22 (90.09\%) & & $2 \mu \mathrm{l}$ cDNA per reaction \\
\hline & & & & In total $5 \%$ & & \\
\hline
\end{tabular}

PB - peripheral blood; MNC - mononuclear cells; RT - reverse transcription; RT PCR - nested PCR; NA - non available; WBC - white blood cells 
age in these studies, which recorded the following incidence values in $\mathrm{UCB} / \mathrm{GC}$ of newborns, in $\mathrm{PB}$ of children, and in $\mathrm{PB}$ of adults: $0 / 22(0 \%), 1 / 22(4.5 \%)$, and $22 / 73(30.1 \%)$ in first, $2 / 10$ (20\%), 11/30 (36.7\%), and 21/32 (65.6\%) in second, and, finally N/A, 4/44 (9.1\%), and 15/145 (10.3\%) in third study, respectively $[30,35,36]$. Overall, the data on the incidence of BCR-ABL p210 transcripts in PB of healthy children are very limited. The recently published results by Ismail et al. [30] show a slightly higher incidence rate $(4 / 44 ; 9.1 \%)$ than that reported by Biernaux et al. (1/22; 4.5\%), but much lower than the incidence recorded by Song and colleagues, namely $36.7 \%$ (11/30) [35]. In terms of sensitivity of the method, the study of Biernaux and colleagues stands up due to very high sensitivity of a novel RT PCR method allowing them to detect 1 copy of BCR-ABL p210 RNA in an equivalent quantity of $10^{8}$ cells. The RT PCR optimization was achieved by (i) increasing the amount of total RNA in reverse transcription reaction from a standard $1 \mu \mathrm{g}$ to up to $10 \mu \mathrm{g}$ (ii) spending entire cDNA for $1^{\text {st }}$ round PCR amplification, and (iii) using $1 / 10$ of $1^{\text {st }}$ PCR for nested PCR. The authors declare the adherence to very strict conditions and controls when performing all experiments [36]. However, the amount of screened subjects, especially in the group of children, is relatively very low $(n=22)$, therefore, the statistical relevance of the data is limited. On the other hand, more recent study by Ismail and colleagues [30] recorded higher incidence, paradoxically using a method with twoorders lower sensitivity on the sample of 2 -fold larger size ( $\mathrm{n}=$ 44). The data of Song and colleagues [35] are questionable due to several fold higher incidence as compared to other available reports, which might likely be caused by cross-contamination of samples during nested PCR.

Relationship of $B C R-A B L$ incidence to the gender has also been analyzed. While the study of Ismail et al. [30] indicated higher risk of p210 fusion for males at 12/98 (12.2\%) against females at 7/91 (7.7\%), the study by Boquet et al. has reported p210 fusion transcripts only in females $(2 / 30,6.7 \%)$ [37]. The p190 transcripts have not shown any correlation with age or gender $[30,35]$. However, approximately a 2 -fold higher incidence of p190 than 210 fusion transcripts has been detected within the study of Song et al. in children and adults, 80\%:62\% and 61\%:32\%, respectively [35]. Similar ratio between p190 $(11 / 16)$ and p210 (4/15) fusion transcripts has been previously observed by Bose et al. in adults (69\% and 27\%, respectively). With respect to the sensitivity of the method, Bose and colleagues used a modified nested PCR assay analyzing the total amount of cDNA synthesized from $10^{8}$ white blood cells (WBC) in 40 replicate PCR tests, achieving a relatively high sensitivity of the screening method, i.e. $10^{-5}$ to $10^{-6}$. The two groups, Biernaux's and Bose's, achieved very similar incidence of p210 fusion transcript in healthy adults, namely $4 / 15$ (27\%) and $22 / 73(30 \%)$. However, the validity of the results is limited due to small size of the screened samples. Contradictorily, this incidence has not been confirmed in the study by Ismail et al., where the p190 transcript was not detectable by nested PCR in healthy children and adults [30]. Of note, the usefulness of the results stemming from Song's and Bose's studies for the assessment of the $B C R-A B L$ incidence is very limited due to low statistical power and reduced reliability of the two-tube nested PCR, which was used in these studies.

In 1995, Biernaux et al. for the first time investigated $B C R-A B L$ in UCB of healthy individuals [36]. This group failed to detect this transcript in very limited number of analyzed UCB (0/22), although using nested RT PCR approach with the highest sensitivity level recorded so far $\left(1 \times 10^{-8}\right)$. Recently, several groups extended studies on $B C R-A B L$ in UCB. Song et al. reported a high $42 \%$ (21/50) incidence of $B C R-A B L \mathrm{p} 190$ and $16 \%(8 / 50)$ incidence of $B C R-A B L \mathrm{p} 210$ transcripts in UCB [35]. Again, the number of subjects (50) enrolled in this study was too low to make any conclusion. In addition, the method used (two-tube nested PCR) may have lower reliability due to very high risk of cross-contamination, even though the authors state that the $2^{\text {nd }}$ round PCR was performed in a different building. Evidently, the incidence of $B C R-A B L$ fusion transcripts in UCB as well as in other sources reported by Song et al, highly exceed the incidences estimated by all other groups. Our research group defined significantly lower incidence of $B C R-A B L$ p 190 in UCB, i.e. $6.25 \%$ on 200 subjects and later refined to $5 \%$ on 500 subjects $[26,28]$. Moreover, one research group has investigated the presence of $B C R-A B L$ transcripts in fetal $\mathrm{BM}$, fetal liver and infant BM without finding any positive samples [38]. However, this study suffers from low number of screened samples, namely 13 fetal livers, 16 fetal BM and 6 infant BM. The sensitivity of their PCR derived for MLL-AF4 was significantly lower as compared to ours, achieving about $1 \%$ of $M L L-A F 4^{+}$ cells in $10^{7}$ total cell number $\left(1 \times 10^{-2}\right.$ sensitivity) whereas the nested PCR was 100 -fold more sensitive ( $1 \times 10^{-4}$ sensitivity). However, the sensitivity of the $B C R-A B L$ assay, which may differ from the $M L L-A F 4$ sensitivity, was not determined, thus contributing to drawbacks of this study. Similarly, the specificity of $B C R-A B L$ analysis was limited, in contrast to that of $M L L-A F 4$, which was remarkable and consisted of several complementing techniques.

The presence of $B C R-A B L$ p 210 positive cells in $\mathrm{PB}$ of healthy adults has been estimated only sporadically, ranging values from about $10^{-4}$ to up to $10^{-8}[35,36,39]$. In general, these data are likely inaccurate, representing only rough estimates of actual frequencies due to low statistical power of the studies and high risk of cross-contamination of the nested PCR screening method. However, the presence of $B C R-A B L$ fusion gene in healthy subjects was further substantiated by more recent case reports reliably showing $\mathrm{t}(9 ; 22) / B C R-A B L$ p210 chromosomal translocation in asymptomatic subjects who never developed CML. One of the case reports [40] describes a 39 -year old male with elevated WBC of $15,000 / \mu l$, but otherwise asymptomatic, with no evidence of any cytogenetic or molecular abnormalities, with an exception of the presence of $B C R-A B L$ detected in 51 of 300 cells in his peripheral blood by FISH and RT qPCR. In addition, FISH for $\mathrm{t}(9 ; 22) / B C R-A B L$ was tested positive in $52 \%$ of $\mathrm{BM}$ cells. The patient continued to 
be asymptomatic at 1-year of surveillance. Another case report shows data on a 71-year old male presented with a lesion under his right eye, with $\mathrm{WBC}$ of $6,600 / \mu \mathrm{l}$ and a moderate increase in myeloid precursors in BM [41]. FISH analysis confirmed the findings of cytogenetics in both $\mathrm{BM}$ (62.5\% of cells positive for BCR-ABL) and in $\mathrm{PB}$ (73.5\% positivity), these data may suggest a relatively high proportion of $\mathrm{p} 210^{+}$cells present in $\mathrm{BM} / \mathrm{PB}$ of an asymptomatic individual. Despite the fact that this man was asymptomatic, he underwent a treatment with imatinib and achieved a major molecular response exhibiting as a significant decrease of $B C R-A B L$ copy number estimated by RT qPCR. In these two case reports, $B C R$ - $A B L$ positivity has been proved by FISH method as an essential technique for the cytogenetic identification of the $\mathrm{Ph}$ chromosome. Different groups have reported FISH sensitivity of $98 \%$ with false positive results of 2.3 to $2.8 \%$ [42]. However, the observed false positivity of FISH is usually clinically non-significant, because it is always backed by cytogenetic metaphase and RT qPCR analysis of $\mathrm{PB}$ or BM cells.

The validation of the results is a very important part of the screening process due to the risk of false positivity associated with the PCR-based methods. The majority of the methods for PFG screening are RNA-based techniques consisting of analysis of cDNA that was in vitro reversely transcribed from the particular mRNA molecules. Due to the occurrence of the trans-splicing phenomenon, although at extremely low frequency, these methods may identify preleukemic fusion transcripts even in the absence of corresponding chromosomal translocation, thus producing false positivity.

Therefore, the DNA-based methods, such as FISH or flow FISH would be preferable, although their sensitivity is too low when we assume relatively very low amount of positive cells/signal present in analyzed samples. The trade-off is the analysis of fusion transcripts. They can be verified by sequencing of the PCR products to prove formation of a correct, i.e. in frame fusion between the two hybrid genes. In addition, the data might be further validated by repetitive screening performed by either the same or different group (e.g. reference or certified laboratory). Table 1 summarizes validation of $B C R-A B L$ incidences which was performed in limited number of studies, including Biernaux et al (1995) and two reports from our laboratory $[26,28]$. Direct sequencing of $B C R-A B L$ p210 PCR-products by Biernaux and colleagues revealed the presence of correct sequence junction between BCR exon3 and $\mathrm{ABL}$ exon2 (junction b3a2) in $100 \% \mathrm{p} 210^{+}(23 / 23)$ samples [36]. Similarly, our group reported high percentage of validation of $B C R-A B L$ p190 by sequencing, namely $90.1 \%$ $(20 / 22)$ [28]. In addition, we reported a repeated RT qPCR screening of selected $B C R-A B L \mathrm{p} 190^{+}$samples performed either in a reference laboratory located outside with $26.7 \%$ (4/15) concordance [26] or in our laboratory achieving similar validation rate, namely $30 \%$ (27/90) [28]. These data suggest that approximately $1 / 3$ of $190^{+}$samples have been confirmed by repeating the screening using the same RT qPCR method. This relatively low validation rate could be explained by an extremely low copy number of the p190 PFG in the analyzed samples, which was close to the threshold of the sensitivity of the screening method $\left(1-3 \times 10^{-5}\right.$ for RT qPCR in our laboratory), therefore limiting determination of the exact $\mathrm{PFG}$ values. It is obvious that both these validation methods cannot confirm the presence of corresponding chromosomal translocation as it FISH method allows. However, FISH technique cannot be applied for PFG screening in UCB mononuclear cells (MNC) due to its insufficient sensitivity.

The available data on the incidence of $B C R-A B L$ are summarized in Table 1. In the case of $B C R-A B L \mathrm{p} 210$, these data suffer from relatively low statistical power, with an average number of screened samples less than 50. After exclusion of the Song's report showing several-fold higher frequencies of PFG than all other studies, we take into consideration results of five reports. In children's PB, the overall p210 incidence may be estimated in the range between $4.5 \%$ up to $9.1 \%, \sim 7 \%$ [30, 36]. In adult's $\mathrm{PB}$, the incidence may be enhanced from $6 \%$ up to $30 \%, \sim 18 \%[30,36,37,39]$. The frequency of $B C R-A B L$ p210 in UCB cannot be estimated due to insufficient data, however, the data of Biernaux and colleagues reporting none positives among 22 samples [36] may suggest a significantly lower p210 incidence in cord blood than in children, thus supporting the upward tendency of p210 incidence with age. Based on the results published in two recent studies by our group, the incidence of $B C R-A B L \mathrm{p} 190$ may be estimated to about $5-6 \%$ in UCB $[26,28]$. These data are supported by (i) sufficient statistical power of the two studies, counting 200 and 500 screened samples, respectively, (ii) using a screening method with extremely low risk of cross-contamination, and (iii) applying several levels of data validation. On the other hand, the data on the incidence of $B C R-A B L$ p190 in both children and adults are insufficient, and obviously new studies are required to validate the aforementioned estimates.

TEL-AML1 fusion gene. The incidence of TEL-AML1 has repeatedly been investigated in UCB of healthy individuals (Table 2). In 2002, the study of Mori et al. has reported that the incidence of TEL-AML1 fusion transcript in UCB is $1.05 \%$ [2]. This study was the first one to detect PFG in healthy individuals using RT qPCR. This method reached a sensitivity of $10^{-4}$ and confirmed all positive results obtained by the initial nested RT PCR (6/567) at the same sensitivity [2]. The reported results seem to be very reliable due to high statistical power of the study (567 probands) although a risk of cross-contamination in the first nested RT PCR cannot be excluded. Moreover, this group used a flow cell sorter and immunomagnetic beads to sort subpopulations of Tlymphocytes $\left(\mathrm{CD}^{+}\right)$, B cell lineage $\left(\mathrm{CD} 19^{+}\right)$, monocytes $(\mathrm{CD} 14+)$, and rare $\mathrm{HSC} / \mathrm{PC}\left(\mathrm{CD} 34^{+}\right)$populations from 4 positive UCB samples, followed by nested RT PCR (in 1 sample) or FISH analyses (in 3 samples). Nested RT PCR revealed positivity in sorted CD19+ and $\mathrm{CD} 34^{+}$subpopulations. These cell populations represent respectively $80 \%$ and $1.5 \%$ of non-sorted UCB MNC, while both membrane markers, $\mathrm{CD} 19^{+}$and $\mathrm{CD} 34^{+}$, usually characterize blasts from children with TEL-AML1 B-precursor ALL. 
Table 2. Incidence of TEL-AML1 in healthy subjects

\begin{tabular}{|c|c|c|c|c|c|c|}
\hline Studies & Source & Methods & Sensitivity & $\begin{array}{l}\text { TEL-AML1 positive/ } \\
\text { examined subjects } \\
\text { (incidence, \%) }\end{array}$ & $\begin{array}{l}\text { Comments } \\
\text { (Age) }\end{array}$ & Analyzed sample \\
\hline Eguchi-Ishimae (2001) & $\begin{array}{l}\mathrm{UCB} \\
\mathrm{PB}\end{array}$ & $\begin{array}{l}\text { Nested PCR } \\
\text { Nested PCR } \\
\text { Sequencing }\end{array}$ & $\begin{array}{l}10^{-5} \\
10^{-5}\end{array}$ & $\begin{array}{l}1 / 67(1.5 \%) \\
11 / 99(11 \%) \\
2 / 48(4 \%) \\
13 / 13(100 \%)\end{array}$ & $\begin{array}{l}<20 \text { years } \\
>20 \text { years }\end{array}$ & $\begin{array}{l}\text { MNC } \\
\text { Total RNA }\end{array}$ \\
\hline Mori (2002) & UCB & $\begin{array}{l}\text { RT qPCR } \\
\text { Nested PCR } \\
\text { Sequencing } \\
\text { Sorting + FISH }\end{array}$ & $\begin{array}{l}10^{-4} \text { or above } \\
10^{-4}\end{array}$ & $\begin{array}{l}6 / 567(1 \%) \\
6 / 567(1 \%) \\
6 / 6(100 \%) \\
2 / 3(66 \%) \\
\text { In total } \sim 1 \%\end{array}$ & & $\begin{array}{l}1 \mathrm{x} 10^{6} \mathrm{MNC} \\
4 \mu \mathrm{g} \text { RNA to cDNA } \\
1 \mu \mathrm{cDNA}(1 / 40 \mathrm{cDNA}) \text { per RT } \\
\mathrm{qPCR} \text { reaction } \\
2 \mu \mathrm{cDNA} / 1 \text { round, } 1 \mu \mathrm{cDNA} / 2 \\
\text { round RT PCR }\end{array}$ \\
\hline Olsen (2006) & PB & $\begin{array}{l}\text { RT qPCR } 1 \\
\text { RT qPCR } 2 \\
\text { Nested PCR } \\
\text { Dot blot } \\
\text { Sequencing }\end{array}$ & $\begin{array}{l}10^{-4}-10^{-5} \\
10^{-4}-10^{-5} \\
10^{-4}-10^{-5}\end{array}$ & $\begin{array}{l}13 / 2005(0.6 \%) \text { tube } \mathrm{A} \\
0 / 13(0 \%) \text { tube } \mathrm{B} \\
0 / 5(0 \%) \text { tube } \mathrm{B} \\
10 / 13(76 \%) \text { tube } \mathrm{A} \\
3 / 9(30 \%) \text { tube } \mathrm{A} \\
\text { In total }<0.5 \%\end{array}$ & Adults & $\begin{array}{l}\geq 1.6 \times 10^{6} \mathrm{MNC} \\
12 \mu \mathrm{l}(24 \%) \mathrm{mRNA} \text { to cDNA } \\
10 \mu \mathrm{l} \mathrm{cDNA}(12 \% \text { mRNA) per RT } \\
\text { qPCR reaction } \\
5 \mu \mathrm{l} \text { cDNA/1 round, } 1 \mu \mathrm{l} \mathrm{cDNA} / 2 \\
\text { round RT PCR }\end{array}$ \\
\hline Lausten-Thomsen (2008) & $\begin{array}{l}\text { BM from embryos } \\
\text { tissues }\end{array}$ & $\begin{array}{l}\text { RT qPCR } \\
\text { Sorting }\end{array}$ & $10^{-4}$ to $10^{-5}$ & $0 / 27(0 \%)$ & $43-66 d$ & MNC - within 2-4h \\
\hline Lausten-Thomsen (2010) & $\begin{array}{l}\text { UCB } \\
\text { (prematurely born } \\
\text { children) }\end{array}$ & $\begin{array}{l}\text { RT qPCR1 } \\
\text { Dot blot } \\
\text { RT qPCR2 }\end{array}$ & $\begin{array}{l}10^{-4}-10^{-5} \\
10^{-4}-10^{-5}\end{array}$ & $\begin{array}{l}1 / 256(0.4 \%) \\
0 / 1(0 \%) \\
0 / 1(0 \%)\end{array}$ & & $\begin{array}{l}\text { Median } 7.8 \times 10^{6} \mathrm{MNC} \\
12 \mu \mathrm{l}(24 \%) \mathrm{mRNA} \text { to cDNA } \\
10 \mu \mathrm{l} \text { cDNA }(12 \% \text { mRNA }) \text { per } \\
\text { RT qPCR }\end{array}$ \\
\hline Zuna (2011) & $\begin{array}{l}\text { UCB } \\
\text { Aborted fetuses } \\
\text { (liver and spleen) }\end{array}$ & $\begin{array}{l}\text { Nested PCR } \\
\text { or RT qPCR } \\
\text { FISH } \\
\text { NA }\end{array}$ & $\begin{array}{l}\text { NA } \\
\text { NA } \\
\text { NA }\end{array}$ & $\begin{array}{l}5 / 253(2 \%) \\
1 / 5(25 \%) \\
1 / 12(8 \%)\end{array}$ & & NA \\
\hline Lausten Thomsen (2011) & UCB & $\begin{array}{l}\text { RT qPCR } 1 . \\
\text { RT qPCR } 2 . \\
\text { Dot blot } \\
\text { Sorting+RT qPCR }\end{array}$ & $\begin{array}{l}10^{-4}-10^{-5} \\
10^{-4}-10^{-5}\end{array}$ & $\begin{array}{l}14 / 1417(0.9 \%) \\
0 / 14(0 \%) / \\
9 / 14(64 \%) / 0.6 \% \\
0 / 14(0 \%)\end{array}$ & $\begin{array}{l}\text { Tube A } \\
\text { Tube B } \\
\text { Tube A } \\
\text { Cells in } \mathrm{N}_{2}\end{array}$ & $\begin{array}{l}\geq 2.5 \times 10^{6} \mathrm{MNC} \\
18 \mu \mathrm{l}(36 \%) \mathrm{mRNA} \text { to cDNA } \\
10 \mu \mathrm{c} \text { cDNA ( } 12 \% \text { mRNA) per RT } \\
\text { qPCR reaction }\end{array}$ \\
\hline Olsen (2012) & UCB & $\begin{array}{l}\text { RT qPCR } 1 \\
\text { RT qPCR } 2 \\
\text { Dot blot } \\
\text { Sequencing }\end{array}$ & $\begin{array}{l}10^{-4}-10^{-5} \\
10^{-4}-10^{-5}\end{array}$ & $\begin{array}{l}3 / 1258(0.24 \%) \\
0 / 3(0 \%) \\
3 / 3(100 \%) \\
2 / 3(66 \%)\end{array}$ & $\begin{array}{l}\text { Tube A } \\
\text { Tube B } \\
\text { Tube A } \\
\text { Tube A }\end{array}$ & $\begin{array}{l}\geq 1.6 \times 10^{6} \text { MNC } \\
12 \mu \mathrm{l}(24 \%) \text { mRNA to cDNA } \\
10 \mu \mathrm{l} \mathrm{cDNA} \mathrm{(} 12 \% \text { mRNA }) \text { per } \\
\text { RT qPCR }\end{array}$ \\
\hline Barbany (2013) & PB from GC & RT qPCR & $10^{-3}-10^{-4}$ & $0 / 30(0 \%)$ & & RNA from $6 \times 10^{5} \mathrm{MNC}$ \\
\hline Skorvaga (2014) & UCB & $\begin{array}{l}\text { RT qPCR } 1 \\
\text { RT qPCR2 } \\
\text { Nested PCR } \\
\text { Multiplex PCR }\end{array}$ & $\begin{array}{l}1-3 \times 10^{-5} \\
1-3 \times 10^{-5} \\
1-3 \times 10^{-5} \\
0.2-1 \times 10^{-3}\end{array}$ & $\begin{array}{l}\text { P190 32/200 (16\%) } \\
\text { P190 4/15 (26.6\%) } \\
\text { In total 4\% } \\
\text { P190 0/135 (0\%) }\end{array}$ & & $\begin{array}{l}10^{7} \mathrm{MNC} \\
1 \mu \mathrm{g} \text { total RNA to RT } \\
2 \mu \mathrm{l} \text { cDNA per } \mathrm{RT} \text { qPCR reaction }\end{array}$ \\
\hline Ornelles (2015) & UCB & $\begin{array}{l}\text { Nested PCR } \\
\text { Sequencing }\end{array}$ & NA & $\begin{array}{l}5 / 210(2.4 \%) \\
5 / 5(100 \%)\end{array}$ & & $\begin{array}{l}10^{6} \text { lymphocytes } \\
200 \text { ng RNA to RT } \\
5 \mu \mathrm{l} \text { cDNA/1 round, } 3 \mu \mathrm{cDNA} / 2 \\
\text { round RT PCR }\end{array}$ \\
\hline Kosik (2015) & UCB & $\begin{array}{l}\text { RT qPCR } 1 \\
\text { RT qPCR } 2 \\
\text { Sequencing }\end{array}$ & $\begin{array}{l}1-3 \times 10^{-5} \\
1-3 \times 10^{-5}\end{array}$ & $\begin{array}{l}45 / 500(9 \%) \\
27 / 90(30 \%) \\
20 / 22(90.9 \%) \\
\text { In total } 2.4 \%\end{array}$ & & $\begin{array}{l}10^{7} \mathrm{MNC} \\
1 \mu \mathrm{g} \text { total RNA to RT } \\
2 \mu \mathrm{l} \text { cDNA per RT qPCR reaction }\end{array}$ \\
\hline
\end{tabular}

PB - peripheral blood; MNC - mononuclear cells; RT - reverse transcription; RT PCR - nested PCR; NA - non available; A - tube A; B - tube B 
Using cell sorting, this study reached much higher sensitivity. FISH analysis of $\mathrm{CD} 19^{+}$cells for TEL-AML1 also confirmed positivity in 2 out of 3 positive MNC samples at a similar level of $0.25-0.33 \%$. The results by Mori et al. [2] are comparable to the data of Eguchi-Ishimae et al. [43] who have determined incidence of TEL-AML1 equal to $1.5 \%(1 / 67)$ using nested RT PCR with a sensitivity of $10^{-5}$, which was one order of magnitude higher than that used in study by Mori et al. [2]. Although the positive product has been directly sequenced by Eguchi-Ishimae et al., the weaknesses of this study design was in low number of UCB samples (67) and increased risk of contamination caused by two-step nested RT PCR. In line with this study, the Czech group of Trka has reported very similar, $2 \%$, incidence of TEL-AML1 derived from $253 \mathrm{UCB}$ samples [27]. These UCB have been analyzed by either nested RT PCR or RT qPCR, although sensitivity of both methods has not been provided and the methods have not been described. One positive sample was confirmed by FISH, where 3000 nuclei were screened and 3 of them $(0.1 \%)$ contained visible $T E L-A M L 1$ signal. Although the study did not find any TEL$A M L 1$ positive signal by analyzing 5000 negative control cells this number is lower than the false $B C R-A B L$ positive rate of $2.3 \%$ determined by FISH in cells from healthy donor [44]. Following these results, Skorvaga et al., Ornelles et al., and Kosik et al. reported slightly higher frequencies of TEL-AML1 in comparison to the Mori's study, corresponding to $6.25 \%$, $2.4 \%$, and $5 \%$, respectively $[26,28,45]$. The first study from our laboratory by Skorvaga et al. has screened 200 UCB by RT qPCR with a detection limit of 1-3 cells positive among 100,000 cells $\left(10^{-5}\right)$. The data were validated in the reference laboratory by screening 20 positive UCB samples resulting in $25 \%(5 / 20)$ validation rate. The second study from our laboratory by Kosik et al. was the extension of the first study with the aim to get higher statistical power and refine validation rate. In this study, 500 UCB have been screened and 90 samples were validated by RT qPCR. Additionally, validation by sequencing 20/22 (90.01\%) has been included. The study by Ornelles et al., which employed nested RT PCR assay, suggested that $2.4 \%(5 / 210)$ of newborne's UCB contained the TEL-AML1 translocation. This study used statistical power of 210 samples and validation by sequencing $5 / 5(100 \%)$. However, sensitivity of nested RT PCR was not reported.

Contrary to all aforementioned reports, $\sim 100$-fold lower frequencies of TEL-AML1 fusion transcripts have been observed in three studies from the same Danish group. In the first of these studies, UCB was collected from prematurely born children [46]. Initial screening by RT PCR detected only 1 out of 256 samples as TEL-AML1 positive (0.4\%) at Ct value 44.4 below the study detection level $10^{-5}$. The positive product was not confirmed by dot blot hybridization and secondary RT qPCR. The second Danish study initially found $\sim 1 \%(14 / 1417)$ incidence of TEL-AML1 in fresh UCB cells processed within 24 hours [3]. After using dot blot hybridization, from fourteen originally positive samples, only nine were confirmed as positive and thus established the incidence being $0.6 \%$. Re-screening of all positive samples by RT qPCR analysis using second tubes of the same mRNA stored at $-80^{\circ} \mathrm{C}$ did not confirm any fusion transcripts. Similarly, flow cytometric sorting of a B cell lineage $\left(\mathrm{CD} 19^{+}\right)$, $\mathrm{T}$ cell lineage $\left(\mathrm{CD}^{+}\right)$and remaining $\mathrm{CD} 19^{-} / \mathrm{CD} 8^{-}$subpopulations from cryopreserved MNC, representing in average 0.99, 0.613, $6.755 \times 10^{6}$ cells, respectively, revealed no positive findings. Finally, the incidence of TEL-AML1 was estimated to be less than $0.01 \%$. The third study from this group obtained similar results [25]. This study reported the presence of TEL-AML1 transcripts in $3 \mathrm{UCB}$ out of $1258(0.24 \%)$ samples. In contrast to the previous Danish study, only 9 out of $1258(0.7 \%)$ samples were processed until 24 hours and most of them much later: 24-48 hours (680), 49-72 h (288), 73-96 h (316) and > $96 \mathrm{~h}$ (15). A criterion for selection of non-degraded mRNA, based on the comparison of RT qPCR amplification efficiency between TEL-AML1 and ABL control gene, was ABL Ct $\leq$ 24.8. This value would allow detection of TEL-AML1 at the levels of $10^{-4}$ and the $\mathrm{Ct}$ value of 38 . The three samples tested positive by RT qPCR were processed between $24-48 \mathrm{~h}$, and thus in $0.8 \%$ of $378 \mathrm{UCB}$ processed within $48 \mathrm{~h}$ TEL-AML1 fusion gene were determined. Dot blot confirmed positivity in all 3 samples (100\%), whereas sequencing only in 2 of them $(66 \%)$, with no samples being positive in a repeating RT qPCR analysis $0 / 9$ of mRNA stored at $-80^{\circ} \mathrm{C}$. The strength of the Danish studies included: (i) high statistical power of 256 , 1417 and 1258 samples, (ii) testing mRNA instead of RNA (iii) RT qPCR analysis in sorted subpopulations (in one study)

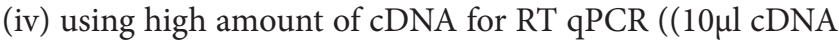
(16\%), 7 times as much mRNA-derived cDNA as Mori et al. in first round PCR screening), (v) higher sensitivity of PCR detection $\left(10^{-5}\right)$ than that by Mori et al. $\left(10^{-4}\right)$ [2] but similar to the studies by Skorvaga and Kosik et al. $\left(10^{-5}\right)[26,28]$. On the other hand, limitation of these studies was validation by post PCR dot blot hybridization without providing sensitivity for TEL-AML1 detection fusion.

Very few studies assessed TEL-AML1 in PB of: (i) neonates [47], (ii) children [43], and (iii) adults [43, 48]. EguchiIshimae et al. have detected that $11 \%(11 / 98)$ and $4 \%(2 / 18)$ of PB from children and adults over 20 years, respectively, were TEL-AML1 positive [43]. Therefore, no correlation with age has been found [43]. Due to the low number of tested samples, the incidence of TEL-AML1 fusion gene cannot be reliably estimated from these data. Olsen $e t$ al. demonstrated significantly lower incidence of TEL-AML1 transcripts in 2005 adult's $\mathrm{PB}(<0.5 \%)$, with a note that their second round of RT qPCR $(0 / 13)$ and nested RT PCR (0/5) with the same sensitivity, from $10^{-4}$ to $10^{-5}$, failed to confirm the results obtained in the first round of single RT qPCR $(13 / 2005,0.65 \%)$; dot blot $(10 / 13,76 \%)$ and sequencing $(3 / 9,33 \%)$ significantly differed in their validation efficiency [48]. This study had the highest statistical power among all TEL-AML1 studies. However, limitation of this study is in using a single reaction for the initial RT qPCR screening, instead of commonly used triplicates. No TEL-AML1 transcript was detected by Barbany et al. in RNA 
isolated from the PB dropped on GC [47]. However, a number of subjects (30) enrolled in this study was too low. In addition, the RT qPCR sensitivity was relatively low, from $10^{-3}$ to $10^{-4}$, and storage conditions could lead to RNA degradation limiting the reliability of this study.

TEL-AML1 fusion transcript was detected in the spleen of one of twelve amortized fetuses (8\%) [27]. No one of human embryos livers $(0 / 27)$ which contained in average $69.6 \% \mathrm{CD}^{+} 4^{+}$ cells were tested positive for TEL-AML1 [49]. However, these studies involved insufficient number of tissue samples to make any conclusion about incidence.

To conclude, while three studies from the same Danish group inclined towards the incidence of PFG identical to the incidence of TEL-AML1+ ALL in children, four independent studies from different laboratories $[2,27,43,45]$ and two our studies $[26,28]$ reported much higher incidence of TEL-AML1 ( 100-fold) than incidence of overt childhood TEL-AML1+ leukemia (Table 2). Except for publications by Mori et al. [2] and Lausten-Thomsen et al. [3] a common limitation of these findings is that the relevance of the cell type harboring the fusion genes to the origination of leukemia was not elaborated.

MLL-AF4 fusion gene. Up to now, only three original articles, one study presented at the European Cancer Congress in 2015 and two letters to the editor have presented data on MLL-AF4 fusion transcripts in healthy individuals (Table 3). Letters to the editor provided only limited information regarding results and methods $[50,51]$. Two our studies, where the RT qPCR has been used for the primary screening UCB $\mathrm{MNC}$, followed by validation analysis as is described in the chapter of TEL-AML1 fusion gene, found MLL-AF4 transcripts in $0.75 \%$ and $0.8 \%$ samples $[26,28]$. Two other studies which used nested RT PCR with the same sensitivity as we used $\left(10^{-5}\right)$ did not detect any MLL-AF4 in UCB (0/60 and 0/103, respectively) $[50,51]$. Of note, these studies analyzed much lower number of subjects as compared to our studies. Song et al. observed that MLL-AF4 occurred with higher frequency $80 \%(8 / 10)$ in $\mathrm{PB}$ of newborns [35], while the other age groups showed a lower range, moving from $40 \%$ to $69 \%$ (52\% in children vs adults). The limitations of this study were mentioned in the chapter $B C R-A B L$ fusion gene. Besides $P B$ and $U C B$, other sources such as fetal liver, fetal BM or neonatal BM have been analyzed. The incidence of $M L L-A F 4$ transcripts was observed by nested RT PCR at high frequency in fetal liver $(5 / 13 ; 38 \%)$, fetal BM $(4 / 16 ; 25 \%)$ and normal infant BM ( $1 / 6$; 17\%) by Uckun and colleagues [38]. Although at relatively low statistical power, this study achieved a notable specificity by using complementary detection and validation methods including: (i) standard cytogenetic technique, (ii) Southern blot analysis of selected samples, namely $7 / 9$ rearrangements resulting in $M L L$ genomic disruption, (iii) re-analysis of 15/17 cytogenetically negative samples by nested RT PCR, and (iv) sequence analysis of selected $M L L-A F 4^{+}$samples, including infants $(\mathrm{n}=3)$ or children $(\mathrm{n}=15)$ with ALL, fetal liver $(\mathrm{n}=5)$ and fetal BM $(\mathrm{n}=2)$. However, these data were not confirmed by the study of Kim-Rouille et al., who detected no positive

Table 3. Incidence of $M L L-A F 4$ gene in healthy subjects

\begin{tabular}{|c|c|c|c|c|c|c|}
\hline Studies & Source & Methods & Sensitivity & $\begin{array}{l}\text { MLL-AF4 positive/exam- } \\
\text { ined subjects (incidence, \%) }\end{array}$ & Comments (Age) & Analyzed sample \\
\hline Uckun (1998) & $\begin{array}{l}\text { Fetal liver } \\
\text { Fetal BM } \\
\text { Neonatal BM }\end{array}$ & $\begin{array}{l}\text { Nested PCR } \\
\text { Nested PCR } \\
\text { Nested PCR } \\
\text { Standard PCR } \\
\text { Southern blot }\end{array}$ & $\begin{array}{l}10^{-4} \\
10^{-4} \\
10^{-4} \\
10^{-2}\end{array}$ & $\begin{array}{l}5 / 13(38 \%) \\
4 / 16(25 \%) \\
1 / 6(17 \%) \\
0 / 35(0 \%) \\
0 / 10(0 \%) \\
\end{array}$ & $\begin{array}{l}\text { Gestational age } \\
15-22 \text { weeks }\end{array}$ & Total RNA \\
\hline Trka (1999) & UCB & Nested PCR & $10^{-4}$ & $0 \%$ & & Total RNA \\
\hline Kim-Rouille (1999) & $\begin{array}{l}\text { UCB } \\
\text { Fetal liver } \\
\text { Fetal BM }\end{array}$ & Nested PCR & $10^{-5}-10^{-6}$ & $\begin{array}{l}0 / 60(63 \%) \\
0 / 8(0 \%) \\
\text { 5/NA (NA } \%) \\
0 / 5(0 \%) \\
\end{array}$ & Unrelated products & mRNA \\
\hline Song (2011) & PB & Nested PCR & $10^{-4}$ & $\begin{array}{l}8 / 10(80 \%) \\
13 / 25(52 \%) \\
19 / 36(52 \%)\end{array}$ & $\begin{array}{l}\text { Newborns } \\
\text { Children }<25 \text { years } \\
\text { Adults }>25 \text { years }\end{array}$ & $\begin{array}{l}8-16 \times 10^{6} \mathrm{MNC} \\
0,5 \mathrm{~g} \text { total RNA for RT } \\
3 \mu \mathrm{lcDNA} / 1 \text { round, } 1 \mu \mathrm{l} \mathrm{cDNA} / 2 \\
\text { round RT PCR }\end{array}$ \\
\hline Skorvaga (2014) & UCB & $\begin{array}{l}\text { RT qPCR } 1 \\
\text { RT qPCR } 2 \\
\text { Nested PCR } \\
\text { Multiplex PCR }\end{array}$ & $\begin{array}{l}1-3 \times 10^{-5} \\
1-3 \times 10^{-5} \\
1-3 \times 10^{-5} \\
0.2-1 \times 10^{-3} \\
\end{array}$ & $\begin{array}{l}\text { P190 6/200 }(3 \%) \\
\text { P190 4/15 }(26.6 \%) \\
\text { In total 0.75\% } \\
\text { P190 0/135 (0\%) }\end{array}$ & & $\begin{array}{l}10^{7} \mathrm{MNC} \\
1 \mu \mathrm{g} \text { total RNA to RT } \\
2 \mu \mathrm{l} \text { cDNA per reaction }\end{array}$ \\
\hline Kosik (2015) & UCB & $\begin{array}{l}\text { RT qPCR } 1 \\
\text { RT qPCR } 2 \\
\text { Sequencing }\end{array}$ & $\begin{array}{l}1-3 \times 10^{-5} \\
1-3 \times 10^{-5}\end{array}$ & $\begin{array}{l}16 / 500(3.2 \%) \\
27 / 90(30 \%) \\
20 / 22(90.9 \%) \\
\text { In total } 0.8 \%\end{array}$ & & $\begin{array}{l}10^{7} \mathrm{MNC} \\
1 \mu \mathrm{g} \text { total RNA to RT } \\
2 \mu \mathrm{l} \text { cDNA per reaction }\end{array}$ \\
\hline
\end{tabular}

MNC - mononuclear cells; RT - reverse transcription, NA - non available 
sample of fetal liver (0/8) despite using nested RT PCR with significantly higher sensitivity $\left(10^{-5}-10^{-6}\right)[51]$. The necessity of applying several complementary validation techniques, especially in clinical practice, can be documented by the case report of a 30-year old $M L L-A F 4^{+}$patient with high risk ALL [52]. Detailed investigation revealed the presence of (i) normal karyotype, $46 \mathrm{XY}$ (cytogenetic analysis), (ii) genomic disruption of $M L L$ (Southern blot), (iii) common MLL-AF4 fusion transcript (RT PCR confirmed by sequencing), and (iv) insertion of 5' MLL sequence into the AF4 locus of chromosome 4 (high-resolution fiber FISH). The patient presented with a high blast cell count, a pre-B phenotype and central nervous system involvement which are classical features of $\mathrm{t}(4 ; 11)$-ALL. However, the karyotype was normal, since the insertion was submicroscopic. A similar insertion mechanism might also occur in $B C R-A B L$ fusions as it has been suggested for the Philadelphia negative $B C R-A B L$ fusions in CML [53, 54]. These cases indicate that even cytogenetically undetectable chromosomal translocations positive for a functional fusion transcript may result into leukemogenesis, thus contributing to the complexity of the screening procedures.

As mentioned in the $B C R-A B L$ fusion gene section, the results and conclusion stemming from the Uckun's report [38] are limited due to small number of screened samples and use of a method with an increased risk of false positivity, although authors stated the use of strict precautions to prevent cross-contamination. Similarly, the sample size of the study by Kim-Rouille et al. [51] counting only $60 \mathrm{UCB}$ and 8 fetal liver samples was too low. The same is valid for the study by Song et al. with 71 samples. From this point of view, only the study of Trka et al. [50] and two our studies [26, 28] provide sample size, namely 103,200 , and 500, respectively, ensuring appropriate statistical power to estimate PFG incidences that can be compared and from which a reliable conclusion may be drawn. While Trka et al. did not find any MLL-AF4 positivity $(0 / 103)$ with $1 \times 10^{-4}$ sensitivity of nested RT PCR, we detected this fusion gene at the incidence of $0.8 \%$ using RT qPCR with sensitivity of $1-3 \times 10^{-5}$. Based on higher statistical power of our studies, we conclude that the incidence of MLL-AF4 in the UCB may be estimated as $0.8 \%$.

AML1-ETO, PML-RARA, CBFB-MYH11 fusion genes. In few studies, relatively rare PFG characteristic for both ALL and AML were investigated in $\mathrm{UCB}, \mathrm{PB}$, and $\mathrm{BM}$ of healthy subjects (Table 4). The AML1-ETO incidence was determined in UCB as $0.2 \%(1 / 496)$ and $40 \%(63 / 156)$ by the study of Mori et al. [2] and the report of Basecke et al. [55], respectively. Out from 63 positive samples, 6 samples were positively re-analyzed $(6 / 6,100 \%)$ in the study by Basecke et $a l$, however, without indicating the sensitivity of the RT qPCR. The difference in results could be explained by (i) higher sensitivity of nested RT PCR $\left(10^{-6}\right)$ used by Basecke et al. in comparison to by Mori et al. $\left(10^{-4}\right)$, (ii) cross-contamination, (iii) low quality RNA extracted from UCB as the authors assume in conclusion. However, no data describing amount of cells used for RNA extraction, quality of RNA and cDNA were reported. Additionally, this study estimated the incidence of

Table 4: Incidence of other PFG in healthy subjects

\begin{tabular}{|c|c|c|c|c|c|c|c|}
\hline Studies & PFG & Source & Methods & Sensitivity & $\begin{array}{l}\text { PFG positive/examined } \\
\text { subjects (incidence, \%) }\end{array}$ & Comments (Age) & Analyzed sample, \\
\hline Mori (2002) & AML1-ETO & $\mathrm{UCB}$ & $\begin{array}{l}\text { RT qPCR } \\
\text { Nested PCR } \\
\text { Sequencing }\end{array}$ & $\begin{array}{l}10^{-5} \\
10^{-5}\end{array}$ & $\begin{array}{l}1 / 496(0.2 \%) \\
1 / 496(0.2 \%) \\
1 / 1\end{array}$ & & $\begin{array}{l}1 \times 10^{6} \mathrm{MNC} \\
4 \mu \mathrm{g} \text { RNA to cDNA } \\
1 \mu \mathrm{l} \text { cDNA }(1 / 40 \mathrm{cDNA}) \\
\text { per RT qPCR reaction } \\
2 \mu \mathrm{l} \text { cDNA/1 round, } 1 \mu l \\
\text { cDNA/2 round RT PCR }\end{array}$ \\
\hline Basecke (2002) & AML1-ETO & $\begin{array}{l}\text { UCB } \\
\text { BM }\end{array}$ & $\begin{array}{l}\text { Nested PCR } \\
\text { RT qPCR }\end{array}$ & $\begin{array}{l}10^{-6} \\
\mathrm{NA}\end{array}$ & $\begin{array}{l}63 / 156(40 \%) \\
6 / 6(100 \%) \\
4 / 18(22 \%)\end{array}$ & Adults: $22-76$ years & NA \\
\hline Song (2011) & $\begin{array}{l}\text { AML1-ETO } \\
\text { PML-RARA } \\
\text { CBFB-MYH11 } \\
\text { MLL-PTD }\end{array}$ & $\begin{array}{l}\text { UCB } \\
\text { PB }\end{array}$ & $\begin{array}{l}\text { Nested PCR } \\
\text { Nested PCR }\end{array}$ & $\begin{array}{l}10^{-3} \\
10^{-3}\end{array}$ & $\begin{array}{l}1 / 10(10 \%) \\
5 / 25(20 \%) \\
7 / 36(19.5 \%) \\
7 / 10(70 \%) \\
10 / 26(38 \%) \\
20 / 38(52 \%) \\
1 / 10(10 \%) \\
0 / 26(0 \%) \\
1 / 32(3.1 \%) \\
40 / 53(75 \%) \\
11 / 14(79 \%) \\
32 / 51(62 \%) \\
39 / 56(69 \%)\end{array}$ & $\begin{array}{l}\text { Newborns } \\
\text { Children }<25 \text { years } \\
\text { Adults }>25 \text { years } \\
\text { Newborns } \\
\text { Children }<25 \text { years } \\
\text { Adults }>25 \text { years } \\
\text { Newborns } \\
\text { Children }<25 \text { years } \\
\text { Adults }>25 \text { years } \\
\text { Newborns } \\
\text { Children }<25 \text { years } \\
\text { Adults }>25 \text { years }\end{array}$ & $\begin{array}{l}8-16 \times 10^{6} \mathrm{MNC} \\
0,5 \mathrm{~g} \text { total RNA for RT } \\
3 \mu \mathrm{l} \text { cDNA/1 round, } 1 \mu \mathrm{l} \\
\mathrm{cDNA} / 2 \text { round RT PCR }\end{array}$ \\
\hline
\end{tabular}

PB - peripheral blood; MNC - mononuclear cells; UCB - umbilical cord blood; RT - reverse transcription; RT PCR - nested PCR; NA - non available 
AML1-ETO in BM of healthy adults at 22\% (4/18). The study of Song et al determined the AML1-ETO incidence in $\mathrm{PB}$ at $18 \%(13 / 71)$ and the sensitivity of nested RT PCR at $10^{-4}$ [35]. The highest incidence was recorded in probands within the age group of 26-40 years (5/10,50\%), however, no significant age correlation was observed. The frequency of $P M L-R A R A$ and $C B F B-M Y H 11$ has not been investigated in UCB so far. These PFG have been analyzed only in PB where PML-RARA and CBFB-MYH11 were detected in 50\% (37/74) and 3\% (2/68) of samples, respectively [35] (Table 4).

Due to considerable limitations such as lack of appropriate validation steps, increased risk of cross-contamination of the applied method and small number of samples analyzed in the study of Song et al it is premature to draw any conclusion. Moreover, substantial differences in the incidence of AML1-ETO between studies by Mori et al. and Basecke et al. do not allow to reliably estimate the incidence of this PFG in UCB.

\section{Discussion}

A number of studies have demonstrated the occurrence of PFG in the blood of seemingly healthy individuals (table 1, table 2 , table 3 and table 4 ). In this review, we have compared and summarized the results of reports studying the incidence of PFG typically associated with acute/chronic leukemia in $\mathrm{UCB}, \mathrm{BM}$, and $\mathrm{PB}$ of healthy subjects. Moreover, we have reviewed a few case reports of asymptomatic or leukemic patients to demonstrate the complexity of diagnostic and screening process. We have focused on the methodological aspect of the screening approaches with the accent on the statistical power of data, the sensitivity and specificity of the screening techniques, and the validation of the data. By applying all these criteria, we were able to make estimations of PFG incidence among healthy subjects as follows: (i) $B C R-A B L$ p210 in peripheral blood at 7\% in children, and $~ 18 \%$ in adults, supporting an upward trend of p 210 incidence with age, which may be accounted for age dependent genetic instability (ii) BCR-ABL p190 in UCB at 5-6\%, (iii) TEL-AML1 in $\mathrm{UCB}$ at $\sim 1-2 \%$, and (iv) MLL-AF4 in UCB at $\sim 0.8 \%$. In general, there is a notable variation of the PFG incidence in healthy subjects regardless of sample source (UCB, BM and PB) and age group (newborns, children, and adults) studied. Several factors may contribute to the observed variation, including: (i) relatively low statistical power and low number of studies, (ii) inconsistent methodology in terms of diverse sensitivity, specificity and susceptibility to contamination of applied techniques, (iii) insufficient or even absent validation of the results in some reports, and (iv) ethnic, geographical or environmental factors. In particular, the differences in sample processing and methodology may have a substantial influence on the final results even when the same PCR-based method used in different laboratories. Here are some of the major methodological issues: (i) cell type used, (ii) analysis of total RNA versus mRNA, (iii) different amount of cells used for RNA isolation $\left(0.8 \times 10^{6}-1 \times 10^{8}\right)$ and (iv) various quantity

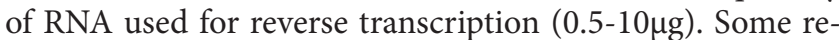
ports did not clearly specify the amount of RNA used in RT reaction, e.g. showing only its volume without indicating the concentration of RNA. There was a marked variability in the sensitivity assessment of the applied method among different groups, for example different molecules or cells were tested and diluted, such as DNA in DNA, RNA in RNA, negative cell line in positive cell line, or cells from leukemia patients in cells from healthy donors. After taking into consideration all above mentioned factors and differences in the reviewed reports, it is not surprising that the sensitivity of nested RT PCR and RT qPCR has been reported in the range of $10^{-4}$ to $10^{-8}$ and $10^{-4}$ to $10^{-5}$, respectively.

Overall, the data available in scientific literature indicate that the PFG frequencies in healthy subjects vastly exceed the incidence of leukemia in human population. In general, the data on the incidence of TEL-AML1 in UCB support Model A which assumes that the initiating genetic event, i.e. $t(12 ; 21)$ chromosomal translocation resulting into TEL-AML1 fusion occurs at relatively high proportion $(\sim 1 \%)$ of newborns [56]. Taking into consideration the cumulative incidence of TEL-AML1 $1^{+}$ALL in children (1:10,000, i.e. $\left.0.01 \%\right)$, it predicts that $\sim 1$ of 100 newborns harboring detectable TEL-AML1 transcripts are destined to develop ALL [56]. Even lower proportions between PFG in cord blood and acute pediatric leukemia incidences have been reported for $B C R-A B L$ and $M L L-A F 4$.

The relevance of studies on PFG screening from the point of risk for leukemia represents the fundamental question. There is a compelling evidence, including retrospective analysis of GC, that several PFG associated with specific chromosomal translocations and acute pediatric leukemia, i.e. $M L L-A F 4$, TEL-AML1, and AML1-ETO often originate prenatally in utero during embryonic/fetal development [57, 58, 59]. However, most of the supporting studies on GC reported the presence of specific chromosomal translocations in limited proportion of studied cases. For example, in one of the first such study the authors were able to detect the $\mathrm{t}(12 ; 21)$ chromosomal translocation resulting into TEL-AML1 in 9/12 Guthrie cards from children with TEL-AML1+ B-ALL [60]. Other reports show the results, e.g. $3 / 3$ for $M L L-A F 4$ without positivity in all tested segments [24], or $5 / 10$ for $t(8 ; 21) /$ AML1-ETO in GC from AML children [61]. These negative neonatal GC/segments could either indicate a postnatal origin of the translocation or more likely its prenatal origin that could not be detected due to (i) insufficient number of positive cells present in the blood spot examined, (ii) degradation of DNA in the sample, or (iii) presence of PCR inhibitors in the tested sample. Therefore, due to these technical drawbacks, bloodspot screening may underestimate the frequency of cases that are originated before birth.

Due to an in utero origin of many PFG, the screening of UCB for the presence of chromosomal translocations commonly associated with leukemia in children as well as in adults 
and giving rise to leukemia-initiating cells (LIC) or cell-oforigin may be the most valuable in terms of risk prediction/ estimation for leukemia and donor-cell derived leukemia (DCL) before allogeneic cord blood transplantation .

With two exceptions, the majority of studies on PFG incidence in UCB so far have been performed on UCB MNC regardless the leukemogenic potential of various cell populations. Thus, the research must be focused on identification of LIC. Although LIC may not be identified for all types of leukemia, these cells must possess the essential stem cell characteristics: (i) self-renewal and (ii) indefinite proliferative potential, which can give rise to leukemic stem cells (LSC) that initiate and maintain the disease. The data have suggested that hematopoietic stem cells (HSC) serve as the cancer-initiating cells for LSC $[62,63]$. It has been demonstrated that all clonogenic capacity resided in $\mathrm{Lin}^{-} \mathrm{CD} 34^{+} \mathrm{CD} 38^{-} \mathrm{AML}$ cells, in contrast to $\mathrm{Lin}^{-} \mathrm{CD} 34^{+} \mathrm{CD} 38^{+}$or $\mathrm{Lin}^{+} \mathrm{AML}$ cells that failed to induce leukemia $[64,65]$. In addition, it has been shown that, the $B C R-A B L 1$ fusion protein can be detected in several hematopoietic lineages of CML patients, suggesting that cellof-origin can be also an early multipotent progenitor (MPP), i.e. an HSC with multilineage differentiation potential [66, $67,68]$. Many lines of evidence support the concept that other more differentiated cells can give rise to LSC after reacquisition of self-renewal (progenitor cell-of-origin) [69, 70]. Moreover, the recent demonstration of some AML LSC expressing even low amounts of lineage markers raised question whether more differentiate hematopoietic cells may serve as cell-of-origin for LSC as well [71]. In case of ALL, it has been demonstrated that expression of TEL-AML1 fusion transcript was detected in a rare population of $\mathrm{CD} 34^{+} / \mathrm{CD} 38^{- \text {llow }} / \mathrm{CD} 19^{+}$ cells $(0.002 \%)$ [72]. In addition, Singer and colleagues showed that $\mathrm{B}$ lineage progenitors, including the pro- $\mathrm{B}$ cell $\mathrm{Lin}^{-} \mathrm{CD}^{+}{ }^{+} /$

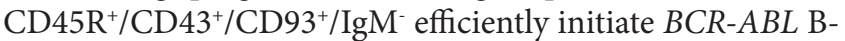
ALL after transplanting them into sublethally irradiated Rag $1^{-{ }^{-}}$ mice [73]. Altogether, these results are encouraging in efforts to identify cell-of-origin for LSC in both ALL and AML.

Obviously, screening MNC from UCB and similarly, BM and $\mathrm{PB}$, cannot give the answer to the question how the identified fusion genes will increase the risk for leukemia in their carriers during their development. Depending on how many samples tested positive for a particular PFG actually contain the corresponding chromosomal translocation in the HSC/ $\mathrm{PC}$, i.e. in cells with leukemogenic potential, the resulting risk for leukemia can be in the range from 0 to $100 \%$. Again, this is a very broad interval and the screening performed in cell populations with self-renewal potential may greatly reduce this range. An intriguing question may be how many children carrying a long-term HSC (a very primitive, extremely rare stem cell in $G_{o}$ phase) stricken by $1^{\text {st }}$ hit will get leukemia versus those children in which the initial translocation arose in short-term progenitor cell. We assume that further research on identification of cell-of-origin for ALL, AML and CML will continue and hopefully will allow us to define the cell populations within UCB that can give rise to LSC. We think that it is necessary to introduce new screening approaches which would allow to target leukemogenic cells, i.e. hematopoietic stem/progenitor cells and to exclude more mature and differentiated cells which are not capable of self-renewal.

The research effort should be directed towards characterization and definition of the target cell populations where the preleukemic lesions initially arise. In this way, the specificity of the screening will be much higher and RNA-based methods as for example qPCR could be substituted with DNA-based methods such as flow-FISH, thus further increasing the specificity of the screening by reduction of false positives that might be formed by alternative splicing. In the context of acute leukemia, it is generally accepted that the process of malignant transformation, i.e. generation of a neoplastic clone with deregulated growth properties, involves the acquisition of several genetic and epigenetic alterations likely in HSC/PC. These alterations lead to conversion of normal HSC/PC into a LSC which is capable of propagating the leukemic clone. However, these LSC are quite rare and their numbers are different depending on their origin. In RT qPCR which was used for PFG screening of UCB in our laboratory, normally $1 \mu \mathrm{g}$ of total RNA was used for cDNA synthesis which at an average concentration of $1-2 \mathrm{pg}$ RNA/cell is equivalent to $500,000-$ $1,000,000 \mathrm{MNC}$. As a standard, 1/10 of cDNA was applied in subsequent RT qPCR which is equivalent to 50,000 - 100,000 MNC. In average, 6 copies of $\mathrm{PFG}^{+}$per positive sample was identified among 100,000 MNC, corresponding to $\sim 1000$ CD $34^{+}$cells among which $\sim 4 \%$ may represent more primitive $\mathrm{CD} 34^{+} \mathrm{CD} 38$ - cell population, inhibited in $\mathrm{G}_{0}$ phase [74]. It means that if we find e.g. $\sim 6$ copies of TEL-AML1 ${ }^{+}$PFG per 100,000 UCB MNC, using CD $34^{+}$CD 38 - cell population would require to identify $\sim 6$ positive signals among 120 cells, therefore, flow-FISH technique could be used for an efficient and unambiguous PFG screening with a possibility to estimate the risk of leukemia.

Acknowledgements: This work was supported by the Slovak Research and Development Agency (APVV 0669-10 and APVV-15-0250) and the VEGA Grant Agency (2/0109/15, 2/0106/15) of the Slovak Republic.

\section{References}

[1] LIMPENS J, DE JONG D, VAN KRIEKEN JH, PRICE CG, YOUNG BD et al. Bcl-2/JH rearrangements in benign lymphoid tissues with follicular hyperplasia. Oncogene 1991; 6: 2271-2276.

[2] MORI H, COLMAN SM, XIAO Z, FORD AM, HEALY LE et al. Chromosome translocations and covert leukemic clones are generated during normal fetal development. Proc Natl Acad Sci U S A 2002; 99: 8242-8247. http://dx.doi.org/10.1073/ pnas. 112218799

[3] LAUSTEN-THOMSEN U, MADSENHO, VESTERGAARDTR, HJALGRIM H, NERSTING J et al. Prevalence of t $(12 ; 21)$ [ETV6RUNX1]-positive cells in healthy neonates. Blood 2011; 117: 186-189. http://dx.doi.org/10.1182/blood-2010-05-282764 
[4] KAATSCH P and MERGENTHALER A. Incidence, time trends and regional variation of childhood leukaemia in Germany and Europe. Radiat Prot Dosimetry 2008; 132: 107-113. http://dx.doi.org/10.1093/rpd/ncn259

[5] RABBITTS TH. Chromosomal translocations in human cancer. Nature 1994; 372: 143-149. http://dx.doi. org/10.1038/372143a0

[6] ROWLEY JD. Chromosome translocations: dangerous liaisons revisited. Nat Rev Cancer 2001; 1: 245-250. http:// dx.doi.org/10.1038/35106108

[7] MITELMAN F, JOHANSSON B and MERTENS F. The impact of translocations and gene fusions on cancer causation. Nat Rev Cancer 2007; 7: 233-245. http://dx.doi.org/10.1038/ $\underline{\text { nrc2091 }}$

[8] FERGUSON DO and ALT FW. DNA double strand break repair and chromosomal translocation: lessons from animal models. Oncogene 2001; 20: 5572-5579. http://dx.doi. org/10.1038/sj.onc. 1204767

[9] Lim TH, TIEN SL, LIM P and LIM AS. The incidence and patterns of BCR/ABL rearrangements in chronic myeloid leukaemia (CML) using fluorescence in situ hybridisation (FISH). Ann Acad Med Singapore 2005; 34: 533-538.

[10] MAIA AT, VAN DER VELDEN VH, HARRISON CJ, SZCZEPANSKI T, WILLIAMS MD et al. Prenatal origin of hyperdiploid acute lymphoblastic leukemia in identical twins. Leukemia 2003; 17: 2202-2206. http://dx.doi.org/10.1038/ sj.leu. 2403101

[11] MOORMAN AV. The clinical relevance of chromosomal and genomic abnormalities in B-cell precursor acute lymphoblastic leukaemia. Blood Rev 2012; 26: 123-135. http://dx.doi. org/10.1016/j.blre.2012.01.001

[12] SCHULTZ KR, PULLEN DJ, SATHER HN, SHUSTER JJ, DEVIDAS $M$ et al. Risk- and response-based classification of childhood B-precursor acute lymphoblastic leukemia: a combined analysis of prognostic markers from the Pediatric Oncology Group (POG) and Children's Cancer Group (CCG). Blood 2007; 109: 926-935. http://dx.doi.org/10.1182/blood2006-01-024729

[13] PIETERS R. Infant acute lymphoblastic leukemia: Lessons learned and future directions. Curr Hematol Malig Rep 2009; 4: 167-174. http://dx.doi.org/10.1007/s11899-009-0023-4

[14] EMERENCIANO M, MEYER C, MANSUR MB, MARSCHALEK R and POMBO-DE-OLIVEIRA MS. The distribution of MLL breakpoints correlates with outcome in infant acute leukaemia. Br J Haematol 2013; 161: 224-236. http://dx.doi.org/10.1111/bjh.12250

[15] PUI CH, CARROLL WL and MESHINCHI S. Biology, Risk Stratification, and Therapy of Pediatric Acute Leukemias: An Update (vol 29, pg 551, 2011). Journal of Clinical Oncology 2011; 29: 4847-4847. http://dx.doi.org/10.1200/ LCO.2010.30.7405

[16] PANE F, CIMINO G, IZZO B, CAMERA A, VITALE A et al. Significant reduction of the hybrid BCR/ABL transcripts after induction and consolidation therapy is a powerful predictor of treatment response in adult Philadelphia-positive acute lymphoblastic leukemia. Leukemia 2005; 19: 628-635. http:// dx.doi.org/10.1038/sj.leu.2403683
[17] SCHULTZ KR, CARROLL A, HEEREMA NA, BOWMAN WP, ALEDO A et al. Long-term follow-up of imatinib in pediatric Philadelphia chromosome-positive acute lymphoblastic leukemia: Children's Oncology Group Study AALL0031. Leukemia 2014; 28: 1467-1471. http://dx.doi.org/10.1038/ $\underline{\text { leu. } 2014.30}$

[18] BIONDI A, SCHRAPPE M, DE LORENZO P, CASTOR A, LUCCHINI $G$ et al. Imatinib after induction for treatment of children and adolescents with Philadelphia-chromosome-positive acute lymphoblastic leukaemia (EsPhALL): a randomised, open-label, intergroup study. Lancet Oncol 2012; 13: 936-945. http://dx.doi.org/10.1016/S1470-2045(12)70377-7

[19] SCELO G, METAYER C, ZHANG L, WIEMELS JL, ALDRICH MC et al. Household exposure to paint and petroleum solvents, chromosomal translocations, and the risk of childhood leukemia. Environ Health Perspect 2009; 117: 133-139. http://dx.doi.org/10.1289/ehp.11927

[20] BELSON M, KINGSLEY B and HOLMES A. Risk factors for acute leukemia in children: a review. Environ Health Perspect 2007; 115: 138-145. http://dx.doi.org/10.1289/ehp.9023

[21] GREAVES MF, MAIA AT, WIEMELS JL and FORD AM. Leukemia in twins: lessons in natural history. Blood 2003; 102: 2321-2333. http://dx.doi.org/10.1182/blood-2002-12-3817

[22] CLARKSON BD and BOYSE EA. Possible explanation of the high concoddance for acute leukaemia in monozygotic twins. Lancet 1971; 1: 699-701. http://dx.doi.org/10.1016/ $\underline{\text { S0140-6736(71)92705-X }}$

[23] KOTECHA RS, MURCH A, KEES U and COLE CH. Prenatal, clonal origin of $\mathrm{t}(1 ; 11)(\mathrm{p} 32 ; \mathrm{q} 23)$ acute lymphoblastic leukemia in monozygotic twins. Leuk Res 2012; 36: 46-50. http://dx.doi.org/10.1016/j.leukres.2011.03.014

[24] GALE KB, FORD AM, REPP R, BORKHARDT A, KELLER C et al. Backtracking leukemia to birth: identification of clonotypic gene fusion sequences in neonatal blood spots. Proc Natl Acad Sci U S A 1997; 94: 13950-13954. http://dx.doi. org/10.1073/pnas.94.25.13950

[25] OLSEN M, HJALGRIM H, MELBYE M, MADSEN HO and SCHMIEGELOW K. RT-PCR screening for ETV6-RUNX1positive clones in cord blood from newborns in the Danish National Birth Cohort. J Pediatr Hematol Oncol 2012; 34: 301303. http://dx.doi.org/10.1097/MPH.0b013e3182332268

[26] SKORVAGA M, NIKITINA E, KUBES M, KOSIK P, GAJDOSECHOVA B et al. Incidence of common preleukemic gene fusions in umbilical cord blood in Slovak population. PLoS One 2014; 9: e91116. http://dx.doi.org/10.1371/journal. pone.0091116

[27] ZUNA J, MADZO J, KREJCI O, ZEMANOVA Z, KALINOVA $\mathrm{M}$ et al. ETV6/RUNX1 (TEL/AML1) is a frequent prenatal first hit in childhood leukemia. Blood 2011; 117: 368-369; author reply 370-361.

[28] KOSIK P, SKORVAGA M, DURDIK M, JAKL L, MARKOVA $\mathrm{E}$ et al. Low numbers of preleukemic gene fusion are frequently present in umbilical cord blood without affecting DNA damage response. European Journal of Cancer 2015; 51: S651-S651. http://dx.doi.org/10.1016/S0959-8049(16)31785-3 
[29] BRASSESCO MS. Leukemia/lymphoma-associated gene fusions in normal individuals. Genet Mol Res 2008; 7: 782-790. http://dx.doi.org/10.4238/vol7-3gmr486

[30] ISMAIL SI, NAFFA RG, YOUSEF AM and GHANIM MT. Incidence of bcrabl fusion transcripts in healthy individuals. Mol Med Rep 2014; 9: 1271-1276.

[31] WANG HC, LIU YC, TSAI YF, WU CH, CHO SF et al. Donor cell-derived acute promyelocytic leukemia after allogeneic hematopoietic stem cell transplant. Ann Hematol 2015; 94: 887-888. http://dx.doi.org/10.1007/s00277-014-2280-0

[32] GRATWOHL A, BALDOMERO H, ALJURF M, PASQUINI MC, BOUZAS LF et al. Hematopoietic stem cell transplantation: a global perspective. JAMA 2010; 303: 1617-1624. http:// dx.doi.org/10.1001/jama.2010.491

[33] SHIOZAKI H, YOSHINAGA K, KONDO T, IMAI Y, SHISEKI $\mathrm{M}$ et al. Donor cell-derived leukemia after cord blood transplantation and a review of the literature: differences between cord blood and BM as the transplant source. Bone Marrow Transplant 2014; 49: 102-109. http://dx.doi. org/10.1038/bmt.2013.127

[34] KUROSAWA S, DOKI N, HINO Y, SAKAGUCHI M, FUKUSHIMA K et al. Occurrence of Donor Cell-derived Lymphoid Blast Crisis 24 Years Following Related Bone Marrow Transplantation for Chronic Myeloid Leukemia. Intern Med 2016; 55: 395-397. http://dx.doi.org/10.2169/internalmedicine.55.5400

[35] SONG J, MERCER D, HU X, LIU H and LI MM. Common leukemia- and lymphoma-associated genetic aberrations in healthy individuals. J Mol Diagn 2011; 13: 213-219. http:// dx.doi.org/10.1016/j.jmoldx.2010.10.009

[36] BIERNAUX C, LOOS M, SELS A, HUEZ G AND STRYCKMANS P. Detection of major bcr-abl gene expression at a very low level in blood cells of some healthy individuals. Blood 1995; 86: 3118-3122.

[37] BOQUETT JA, ALVES JR and DE OLIVEIRA CE. Analysis of BCR/ABL transcripts in healthy individuals. Genet Mol Res 2013; 12: 4967-4971. http://dx.doi.org/10.4238/2013. October.24.8

[38] UCKUN FM, HERMAN-HATTEN K, CROTTY ML, SENSEL MG, SATHER HN et al. Clinical significance of MLL-AF4 fusion transcript expression in the absence of a cytogenetically detectable $\mathrm{t}(4 ; 11)(\mathrm{q} 21 ; \mathrm{q} 23)$ chromosomal translocation. Blood 1998; 92: 810-821.

[39] BOSE S, DEININGER M, GORA-TYBOR J, GOLDMAN JM and MELO JV. The presence of typical and atypical BCR-ABL fusion genes in leukocytes of normal individuals: biologic significance and implications for the assessment of minimal residual disease. Blood 1998; 92: 3362-3367.

[40] BAYRAKTAR S and GOODMAN M. Detection of BCR-ABL Positive Cells in an Asymptomatic Patient: A Case Report and Literature Review. Case Rep Med 2010; 2010: 939706. http:// dx.doi.org/10.1155/2010/939706

[41] SPRANKLIN L, GHEITH S AND AGOSTINO N. The Clinical Relevance of Detection of BCR-ABL in an Asymptomatic Patient: A Case Report and Review of the Literature. Annals of Clinical Pathology 2015; 3: 1054.

[42] YANAGI M, SHINJO K, TAKESHITA A, TOBITA T, YANO $\mathrm{K}$ et al. Simple and reliably sensitive diagnosis and monitoring of Philadelphia chromosome-positive cells in chronic myeloid leukemia by interphase fluorescence in situ hybridization of peripheral blood cells. Leukemia 1999; 13: 542-552. http:// dx.doi.org/10.1038/sj.leu.2401383

[43] EGUCHI-ISHIMAE M, EGUCHI M, ISHII E, MIYAZAKI S, UEDA K et al. Breakage and fusion of the TEL (ETV6) gene in immature B lymphocytes induced by apoptogenic signals. Blood 2001; 97: 737-743. http://dx.doi.org/10.1182/blood. V97.3.737

[44] KOWALCZYK JR, GAWORCZYK A, WINNICKA D, LEJMAN M and BABICZ M. Fluorescence in situ hybridization $\mathrm{BCR} / \mathrm{ABL}$ fusion signal rate in interphase nuclei of healthy volunteer donors: a test study for establishing false positive rate. Cancer Genet Cytogenet 2003; 142: 51-55. http://dx.doi. org/10.1016/S0165-4608(02)00767-7

[45] ORNELLES DA, GOODING LR and GARNETT-BENSON C. Neonatal infection with species $\mathrm{C}$ adenoviruses confirmed in viable cord blood lymphocytes. PLoS One 2015; 10 : e0119256. http://dx.doi.org/10.1371/journal.pone.0119256

[46] LAUSTEN-THOMSEN U, MADSEN HO, VESTERGAARD TR, HJALGRIM H, LANDO A et al. Increased risk of ALL among premature infants is not explained by increased prevalence of pre-leukemic cell clones. Blood Cells Mol Dis 2010; 44: 188-190. http://dx.doi.org/10.1016/j.bcmd.2009.12.007

[47] BARBANY G, GAUFFIN F, OFVERHOLM I, KARLSSON H, THORN I et al. The ETV6/RUNX1 fusion transcript is not detected in RNA isolated from neonatal dried blood spots from children later diagnosed with the corresponding leukemia. Leuk Lymphoma 2013; 54: 2742-2744. http:// dx.doi.org/10.3109/10428194.2013.786068

[48] OLSEN M, MADSEN HO, HJALGRIM H, GREGERS J, ROSTGAARD K et al. Preleukemic TEL-AML1-positive clones at cell level of 10(-3) to 10(-4) do not persist into adulthood. J Pediatr Hematol Oncol 2006; 28: 734-740. http://dx.doi. org/10.1097/01.mph.0000243652.33561.0f

[49] LAUSTEN-THOMSEN U, HJALGRIM H, MARQUART $\mathrm{H}$, LUTTERODT M, PETERSEN BL et al. ETV6-RUNX1 transcript is not frequent in early human haematopoiesis. Eur J Haematol 2008; 81: 161-162. http://dx.doi.org/10.1111/ j.1600-0609.2008.01091.x

[50] TRKA J, ZUNA J, HRUSAK O, MICHALOVA K, MUZIKOVA K et al. No evidence for MLL/AF4 expression in normal cord blood samples. Blood 1999; 93: 1106-1107; author reply 1108-1110.

[51] KIM-ROUILLE MH, MACGREGOR A, WIEDEMANN LM, GREAVES MF and NAVARRETE C. MLL-AF4 gene fusions in normal newborns. Blood 1999; 93: 1107-1108.

[52] VON BERGH A, GARGALLO P, DE PRIJCK B, VRANCKX H, MARSCHALEK R et al. Cryptic $t(4 ; 11)$ encoding MLL-AF4 due to insertion of $5^{\prime} \mathrm{MLL}$ sequences in chromosome 4 . Leukemia 2001; 15: 595-600. http://dx.doi.org/10.1038/sj.leu.2402050

[53] HAGEMEIJER A, BUIJS A, SMIT E, JANSSEN B, CREEMERS GJ et al. Translocation of BCR to chromosome 9: a new cytogenetic variant detected by FISH in two Ph-negative, BCR-positive patients with chronic myeloid leukemia. Genes Chromosomes Cancer 1993; 8: 237-245. http://dx.doi. org/10.1002/gcc.2870080406 
[54] VIEIRA L, ALVES AC, MARQUES B, REIS I, JORGE G et al. Insertion of the $5^{\text {' }}$ part of $\mathrm{BCR}$ within the $\mathrm{ABL}$ gene at $9 \mathrm{q} 34$ in a Philadelphia-negative chronic myeloid leukemia. Cancer Genet Cytogenet 1999; 114: 17-21. http://dx.doi.org/10.1016/ S0165-4608(99)00036-9

[55] BASECKE J, CEPEK L, MANNHALTER C, KRAUTER J, HILDENHAGEN $S$ et al. Transcription of AML1/ETO in bone marrow and cord blood of individuals without acute myelogenous leukemia. Blood 2002; 100: 2267-2268. http:// dx.doi.org/10.1182/blood-2002-06-1673

[56] BROWN P. TEL-AML1 in cord blood: $1 \%$ or $0.01 \%$ ? Blood 2011 ; 117: 2-4. http://dx.doi.org/10.1182/blood-2010-09-304337

[57] FORD AM, RIDGE SA, CABRERA ME, MAHMOUD H, STEEL CM et al. In utero rearrangements in the trithoraxrelated oncogene in infant leukaemias. Nature 1993; 363: 358-360. http://dx.doi.org/10.1038/363358a0

[58] GREAVES MF and WIEMELS J. Origins of chromosome translocations in childhood leukaemia. Nat Rev Cancer 2003; 3: 639-649. http://dx.doi.org/10.1038/nrc1164

[59] BUENO C, CATALINA P, MELEN GJ, MONTES R, SANCHEZ L et al. Etoposide induces MLL rearrangements and other chromosomal abnormalities in human embryonic stem cells. Carcinogenesis 2009; 30: 1628-1637. http://dx.doi. org/10.1093/carcin/bgp169

[60] WIEMELS JL, CAZZANIGA G, DANIOTTI M, EDEN OB, ADDISON GM et al. Prenatal origin of acute lymphoblastic leukaemia in children. Lancet 1999; 354: 1499-1503. http:// dx.doi.org/10.1016/S0140-6736(99)09403-9

[61] WIEMELS JL, XIAO Z, BUFFLER PA, MAIA AT, MA X et al. In utero origin of $\mathrm{t}(8 ; 21)$ AML1-ETO translocations in childhood acute myeloid leukemia. Blood 2002; 99: 3801-3805. http://dx.doi.org/10.1182/blood.V99.10.3801

[62] VISVADER JE. Cells of origin in cancer. Nature 2011; 469: 314-322. http://dx.doi.org/10.1038/nature09781

[63] SHLUSH LI, ZANDI S, MITCHELL A, CHEN WC, BRANDWEIN JM et al. Identification of pre-leukaemic haematopoietic stem cells in acute leukaemia. Nature 2014; 506: 328-333. http://dx.doi.org/10.1038/nature13038

[64] LAPIDOT T, SIRARD C, VORMOOR J, MURDOCH B, HOANG $\mathrm{T}$ et al. A cell initiating human acute myeloid leukaemia after transplantation into SCID mice. Nature 1994; 367: 645-648. http://dx.doi.org/10.1038/367645a0
[65] BONNET D and DICK JE. Human acute myeloid leukemia is organized as a hierarchy that originates from a primitive hematopoietic cell. Nat Med 1997; 3: 730-737. http://dx.doi. org/10.1038/nm0797-730

[66] JONAS D, LUBBERT M, KAWASAKI ES, HENKE M, BROSS $\mathrm{KJ}$ et al. Clonal analysis of bcr-abl rearrangement in T lymphocytes from patients with chronic myelogenous leukemia. Blood 1992; 79: 1017-1023.

[67] MARTIN PJ, HANSEN JA, NOWINSKI RC and BROWN MA. A new human T-cell differentiation antigen: unexpected expression on chronic lymphocytic leukemia cells. Immunogenetics 1980; 11: 429-439. http://dx.doi.org/10.1007/ BF01567812

[68] DEININGER MW, GOLDMAN JM and MELO JV. The molecular biology of chronic myeloid leukemia. Blood 2000; 96: 3343-3356.

[69] JAMIESON CH, WEISSMAN IL and PASSEGUE E. Chronic versus acute myelogenous leukemia: a question of self-renewal. Cancer Cell 2004; 6: 531-533.

[70] GOARDON N, MARCHI E, ATZBERGER A, QUEK L, SCHUH A et al. Coexistence of LMPP-like and GMPlike leukemia stem cells in acute myeloid leukemia. Cancer Cell 2011; 19: 138-152. http://dx.doi.org/10.1016/j. ccr.2010.12.012

[71] SARRY JE, MURPHY K, PERRY R, SANCHEZ PV, SECRETO A et al. Human acute myelogenous leukemia stem cells are rare and heterogeneous when assayed in NOD/SCID/ IL2Rgammac-deficient mice. J Clin Invest 2011; 121:384-395. http://dx.doi.org/10.1172/JCI41495

[72] HONG D, GUPTA R, ANCLIFF P, ATZBERGER A, BROWN $\mathrm{J}$ et al. Initiating and cancer-propagating cells in TEL-AML1associated childhood leukemia. Science 2008; 319: 336-339. http://dx.doi.org/10.1126/science. 1150648

[73] SIGNER RA, MONTECINO-RODRIGUEZ E, WITTE ON and DORSHKIND K. Immature B-cell progenitors survive oncogenic stress and efficiently initiate $\mathrm{Ph}+\mathrm{B}$-acute lymphoblastic leukemia. Blood 2010; 116: 2522-2530. http://dx.doi. org/10.1182/blood-2010-01-264093

[74] STOJKO R AND WITEK A. [Umbilical cord blood--a perfect source of stem cells?]. Ginekol Pol 2005; 76: 491-497. 